\title{
Development of E-Modules Based on Project Based Learning Model for Highway and Bridge Construction Subject at Vocational High Schools
}

\author{
Muvi Yandra ${ }^{1 *}$, Nadra Mutiara Sari ${ }^{1}$ \\ ${ }^{I}$ Dep. of Civil Engineering Education, Faculty of Engineering, Universitas Negeri Padang, Padang, Indonesia, \\ *Corresponding author. Email: muviyandra@ft.unp.ac.id
}

\begin{abstract}
The shifting curriculum into curriculum 2013 also occurs on several productive subjects at Vocational high school in which there is one additional subject, Highway and Bridge Constructions. As this is a new subject, frankly the teacher is required to be able to understand the materials and deliver them to the students. One of proposing ways to deliver the materials is by developing electronic modules, commonly known as e-module, based on project based learning. This e-module uses Moodle (Modular Object Oriented Dynamic Learning Environment) in which the teacher is able to insert teaching materials in the form of text, animation, audio, video as well as assignments and assessments. Moreover, this research is Research and Development (R\&D) with ADDIE development models, namely Analysis, Design, Development, Implementation and Evaluation. The findings showed that the validation of the product was in the good category with slight revision. Furthermore, in terms of respondents' evaluation the results unveiled that respondents felt satisfied in which the respondents' evaluation was in excellent category. Therefore, it can be concluded that e-module eases both teacher and students in teaching and learning highway and bridge construction subject.
\end{abstract}

\section{Keywords: Moodle (e-module), project based learning, highway and bridge construction}

\section{INTRODUCTION}

Education is one of the determining factors to improve human resources; thus, the Government always strives to improve the quality and management of knowledge in various ways such as developing curriculum, facilities, infrastructure, and learning resources, improving the quality of educators, and providing conducive learning atmosphere [1]. Besides, curriculum development is carried out not only in Senior high school but also in Vocational high school, namely the 2017 curriculum revision. One of revisions is the Building Design and Information Design Skills competency which was formerly called the Building Drawing Skills Competency. Moreover, on productive subjects there is a newly added subject, which is called Highway and Bridge Construction subject.

In fact, this shift certainly brought along some impacts on learning process at XI grade in academic year JulyDecember 2018. Based on the results of a survey at SMKN 1 Padang, learning did not seem interactive because it only relied on basic skills. Besides, the learning method implemented was still the old methods, ultimately affecting the learning output both in terms of learning outcomes and training competencies.

As a matter of fact, students' success in the learning process is not only determined by well-trained teachers or a well-designed curriculum, but it is also determined by the learning methods applied by the teacher [2]. Moreover, students' participation in the class is also deemed important. One of the ways to increase the students' involvement during learning process is to implement the appropriate learning model which is Project Based Learning. Project based is an effective educational approach that focuses on creative thinking, problem solving, and interaction between students and their peers to create and use newly acquired knowledge [3].

Based on the aforementioned problems, teaching media that can attract students' interest and build students' independence are certainly needed; therefore, in accordance with the demands of the 2013 curriculum, the center of learning activities that have been on teacher all along, known as teacher-centered, can change towards student, known as student-centered. Then, equipping students with learning materials and resources can be done by providing teaching modules. According to [4], a teaching module will be useful if students can easily use it. Modules are learning tools or learning resources that provide material, methods, limitation, and ways of evaluating that are systematically and attractively designed to achieve the expected competencies according to their level of complexity. Additionally, module is an independent learning package which includes a series of planned learning experiences and 
is systematically designed to help students achieve learning goals [5].

In accordance with Permendikbud No. 65 of 2013 concerning standard process of basic and secondary education, it is explained that the use of information and communication technology to improve efficiency and effectiveness of learning process is certainly needed. As the development of the industrial revolution 4.0 grows stronger, the method of module development is developing as well in which there are electronic modules (e-modules). E-modules utilize information and communication technology in the form of electronic devices. Moreover, the electronic teaching module is a Modular Object Oriented Dynamic Learning Environment (Moodle) in which people can insert and provide animated, audio and video teaching materials as well as assignments and assessments.

One of advantages of using Moodle as teaching material is that it is able to increase students' interest in learning. In addition, it also helps teachers to manage the learning material and develop the material in an interesting and easily understood form [4]. This is surely very helpful for teachers in improving the quality of education. As for students, this module eases them in the learning process since it can be easily accessed. Moreover, students' independence is highlighted in the use of e-modules. Thus, one subject that requires independence is productive subjects [5].

Additionally, compared to conventional books, using Moodle (e-module) as teaching material is more interactive due to its flexibility. With Moodle teachers are able to provide teaching material not only in the form of text but also in form of animation, audio and video. Furthermore, there has been research on E-module. The findings revealed that students' responses on the implementation of problemoriented e-modules were very positive.

Based on above-mentioned problems, the development of e-modules in the learning process is very pivotal since it can be easily modified. Related to this, the researcher carried out research on developing e-module based on project based learning model learning in highway and bridge construction subject at Vocational High Schools.

\section{METHOD}

This study is Research and Development research that emphasizes the ability of research in making a product in the form of materials, media, tools and learning strategies. This type of research is a research method used to produce certain products, and test the effectiveness of the products [6].

The development model used to develop Moodle (emodules) based on project based learning in Highway and Bridge Construction subject is the ADDIE development model. This model was selected due to the fact that this instructional development model can be used to solve complex learning problems and also develop educational and learning products. This model consists of five steps, namely: (1) analysis (2) design, (3) development, (4) implementation, and (5) evaluation.
Table 1. Data Collection Technique

\begin{tabular}{|l|l|l|l|}
\hline No & Type of Data & Method & Data Sources \\
\hline 1 & $\begin{array}{l}\text { Learning source } \\
\text { information }\end{array}$ & Interview & $\begin{array}{l}\text { A teacher of } \\
\text { highway and bridge } \\
\text { construction subject } \\
\text { at SMKN 1 Padang }\end{array}$ \\
\hline 2 & $\begin{array}{l}\text { Students' } \\
\text { characteristics }\end{array}$ & $\begin{array}{l}\text { Question } \\
\text { naire }\end{array}$ & $\begin{array}{l}\text { Grade Eleventh } \\
\text { students at SMKN 1 } \\
\text { Padang }\end{array}$ \\
\hline 3 & $\begin{array}{l}\text { The validity of e- } \\
\text { module }\end{array}$ & $\begin{array}{l}\text { Question } \\
\text { naire }\end{array}$ & $\begin{array}{l}\text { Content expert as } \\
\text { validator } \\
\text { Learning media } \\
\text { expert }\end{array}$ \\
\hline 4 & $\begin{array}{l}\text { Teachers and } \\
\text { students' } \\
\text { responses }\end{array}$ & $\begin{array}{l}\text { Question } \\
\text { naire } \\
\text { Eleacher and grade } \\
\text { SMKN 1 Padant at }\end{array}$ \\
\hline
\end{tabular}

The following formula was used to calculate the percentage of assessment results obtained [7]. (1)

Percentage $=$ Obtained score $x 100 \%$

Max Score

To find out the achievement level of e-module development based on the percentage calculation, criteria are set according to the level of achievement as shown in Table 2.

Table 2. Conversion of Achievement level

\begin{tabular}{|l|l|l|}
\hline $\begin{array}{l}\text { Achievement } \\
\text { Level }(100 \%)\end{array}$ & Category & Note \\
\hline $90-100$ & Very Good & No revision \\
\hline $75-89$ & Good & Slight revision \\
\hline $65-74$ & Sufficient & Adequate revision \\
\hline $55-64$ & Poor & A lot of revision \\
\hline $0-54$ & Very Poor & Recreate \\
\hline
\end{tabular}

Analysis of students' and teachers' responses

The development of this e-module based on project based learning model aims to make the learning stages in the e-module structured and directed and to help add learning resources, learning media, and are expected to improve students' understanding on highway and bridge construction subject.

\section{RESULTS AND DISCUSSION}

The analysis included subject analysis activities which consisted of: a) Analysis of Student Characteristics, b) Analysis of Learning Resources c) Analysis of Objectives and Characteristics of Study Content, d) Establishing Indicators and Learning Content, e) Establishing Strategies for Organizing Learning Content, f) Establishing Strategies for Submitting Learning Content, and g) Establishing Learning Management Strategies

The second stage, namely design, covered the preparation of draft modules and e-module design. Then, it was preceded to the third stage, development. It involved module development activities, e-module development, and 
integration of Moodle features in e-modules. Moreover, module preparation activities involved gathering material, typing instructional materials, and compiling materials in accordance with the Basic Competence in the syllabus implemented.

The next stage is the development of e-modules including developing the design of the Moodle application based on the design of the sitemap, and managing e-module user access rights. In addition, the development of Moodle feature integration in e-modules covered the insertion of the module contents into Moodle which became the final product, e-modules. The development of Moodle features was adapted to the module framework used and contained the implementation stages of the project based learning model on e-modules.

The fourth stage is the implementation. Activities carried out at this stage were testing the e-module in accordance with its role and function in the learning process. It aimed to find out to what extent the benefits of the product have been developed. The trial phase began with a review from experts, and continued with individual, small group, and field trials. The first expert's review conducted was on the content. After completing first review on content, review on design and instructional media was then carried out by the second expert.

The results of the content experts' evaluation showed that the level of achievement of the e-module was "Acceptable" and worthy of continuing. This indicates that the learning materials that have been implemented in the emodule is feasible and can be used in learning. Besides, learning materials in e-module which were selected from several book sources as learning references is declared valid and is in accordance with the basic competencies and learning objectives contained in the syllabus of highway and bridge construction subject. In the content evaluation, the expert merely provided constructive comments and input, so that in the content evaluation, the revision was not required.

Furthermore, the evaluation results from learning design experts on e-module development products consisting of content eligibility, presentation, learning stages of the project based learning model, and learning models have been declared "Good" and are worthy to continue. This suggests that the implementation of the project based learning model in e-module is feasible to be used in highway and bridge construction subject. By applying the steps of the project based learning model in learning, it can make students more active and more independent during learning process.

Moreover, evaluation results from learning media experts consisting of the use of language and readability, graphics, e-module display design, effectiveness, and media developed in the e-module was in "Good" category. The input and suggestions from design expert such as the addition of images or interesting icons at the beginning of the e-module display have been revised in accordance with the suggestions.

The next step is conducting an individual test. Individual test involved three students grade XI at SMK 1 Padang. The selection of the three subjects who became respondents was based on their achievements; one student with high achievement, one student with moderate achievement, and one student with low achievement. From the results of the questionnaire filled out by each student, there was one student who gave a very good response $(33.33 \%)$, two students who gave a good response $(66.67 \%)$, and none of the students gave sufficient responses, poor, or very poor. The average of students' response was $87.52 \%$.

Next, small group test involved 9 students. From the results of a small group trial questionnaire filled out by each student, there were six students who gave very good responses $(66.67 \%)$, four students gave good responses $(33.33 \%)$, and none of the students gave sufficient responses, poor, or very poor. The average rating of twelve students was $88.33 \%$. If converted into a conversion table included in the category, it was in very good category and did not need revision.

After the small group trial activities were completed, it then continued with a field test carried out by fifteen students grade XI at SMKN 1 Padang. From the results of the questionnaire, ten students gave very good responses (23.33\%), five students gave good responses $(77.77 \%)$, and none of the students gave sufficient, poor or very poor responses. The average rating of all field test respondents was $85.74 \%$. If converted into a conversion table of the achievement level, it is categorized good, and there was no need for revision. Based on the findings during the trial test of e-module, students seemed very enthusiastic about following the learning process; they looked very avid in operating e-modules together with other students. In addition, the use of e-modules in the teaching and learning process in the classroom could help students become more responsive, and active, and increase teachers' and students' interaction. Thus, using the project based learning model as a stage in every teaching and learning activity was proven to be able to foster students' participation and independence during teaching and learning activities.

After the field test results are obtained, the next step is taking the teacher's response to the development of emodules in the subject of the construction of highway and bridges subject. The teacher response test was conducted by one respondent, the teacher who taught high and bridge construction subjects. The result of teacher's response has been positive.

Based on the aforementioned discussion, evaluation conducted by content experts, instructional design experts, media experts, and assessment results on individual trials, small group trials, field tests, and the results of teacher responses were categorized "good" and received positive responses. Based on these results, in general the development of e-modules based on the project based learning model of learning in highway and bridge construction subject is deemed successful and is worthy of being used as a source of learning. This is also supported by a number of students' statements. For examples, this emodule makes it easy for students to understand the learning materials; learning by using e-modules is easier to understand, very helpful in group learning; the e-module adds enthusiasm to learn since it is equipped with pictures. 
By implementing the e-module for highway and bridge construction subject, it is highly expected that teachers are able to assist students during learning process and problems during the learning process related to learning resources are able to be overcome. Further, it increases students' active participation, independence, sense of responsibility and initiatives to recognize their learning needs, find sources of information in order to answer their needs, and build and present their knowledge based on the needs and sources found.

\section{CONCLUSIONS}

Based on the results of research conducted, some conclusions are drawn. The development of the e-module for highway and bridge construction subject based on the project based learning model uses the ADDIE development model, where the first stage carried out is an analysis covering the subject analysis activities consisting of: a) Analysis of Student Characteristics, b) Analysis of Learning Resources c) Analysis of the Objectives and Characteristics of the Field of Study Content, d) Establishing Learning Indicators and Content, e) Establishing Strategies for Organizing Learning Content, f) Establishing Strategies for Delivering Learning Content, and g) Establishing Learning Management Strategies. The second stage is the design that includes the preparation of draft modules and e-module design.

The third stage is development which covers module development, e-module development, and integration of Moodle features in e-modules. The fourth stage is the implementation. An activity carried out at this stage is trial aiming to test e-module in accordance with the role and its function in the learning process to find out to what extent the benefits of the product have been developed. The teacher's response to the development of this e-module obtained an average of 41 which can be categorized positive. While in terms of students' responses, the result was 64.74 which was in positive category as well.

Based on the observations, there are several aspects that can be taken into consideration for future research. (1) The development of e-modules in the study limits only for one semester which is for odd semester, so it is expected that future researchers can develop them for one academic year. (2) This study only produces a product in the form of emodule applications; therefore, it is necessary for future research to test the effectiveness of e-modules on student learning outcomes or achievement. (3) It is hopefully useful for those who want to do experimental research or action research to overcome problems in class. (4) Some tests and evaluation comprising of content learning experts, learning design experts, instructional media experts, and limited trials have been carried out to test e-module. However, these tests are not adequate; henceforth, it is also necessary to assess usability and user experience in using e-module systems. (5) For future e-module developers, it is necessary to arrange e-modules more user friendly or easy to use for users who are not yet familiar with computer-based learning.

\section{REFERENCES}

[1] Dimhad. (2014). Penggunaan E-Modul Interaktif Melalui Pembelajaran Berbasis Masalah Untuk Meningkatkan Pemahaman Konsep Sistem Saraf, Kemampuan Generik Sains Dan Berpikir Kritis. Retrieved Januari 20, 2016, from http://dimhad13.110mb.com/buku6/a.pdf.

[2] Winda, M. (2014). Peningkatan Keaktifan Siswa Melalui Penerapan Metode Discovery dalam Pembelajaran PKn di Kelas X2 SMA Negeri 2 Lengayang Pesisir Selatan. TINGKAP, 43-57.

[3] Laviatan, T. (2008). InnovativeTeachingand Assessment Method: QBIand Project Based Learning. MathematicsEducati, 105-116.

[4] Wenno, I. H. (2010). Pengembangan Model Modul IPA Berbasis Problem Solving Method Berdasarkan Karakteristik Siswa Dalam Pembelajaran Di SMP/MTs. Cakrawala Pendidikan, 3-13.

[5] Mulyasa , E. 2004. Kurikulum Berbasis Kompetensi : Konsep, Karakteristik, dan Implementasi . Bandung : Remaja Rosdakarya

[4] Suartama, I. K. (2014). E-learning berbasis moodle. Graha Ilmu.

[5] Fausih, M. (2015). Pengembangan Media E-Modul Mata Pelajaran Produktif Pokok Bahasan "Instalasi Jaringan LAN untuk Siswa Kelas XI Jurusan Teknik Komputer Jaringan di SMK Negeri 1 Labang Bangkalan Madura 1-9.

[6] Sugiyono. (2008). Metode Penelitian Kuantitatif, Kualitatif dan $R$ \& $D$ Bandung: Alfabeta.

[7] Addalena, K. S. (2015). Pengembangan Modul Ajar Pemrograman WEB. 